\title{
THE RELATION BETWEEN POLYAGGLUTINABILITY OF ERYTHROCYTES IN VIVO AND THE HÜBENER- THOMSEN-FRIEDENREICH PHENOMENON
}

\author{
BY
}

\section{J. REEPMAKER}

\begin{abstract}
From the Central Laboratories of the Netherlands Red Cross Blood Transfusion Service, and the University Laboratory of Hygiene, Amsterdam
\end{abstract}

(RECEIVED FOR PUBLICATION DECEMBER 20, 1951)

Hübener (1925) and Thomsen (1927a and b, 1928) were the first to report that erythrocytes from old blood samples might sometimes be agglutinated by sera irrespective of their blood groups; in other words, they become panagglutinable. Friedenreich (1930) demonstrated that this phenomenon, which may be a cause of error in blood grouping, was due to contamination of the blood with certain enzymeproducing bacteria which cause a new agglutinogen, " $T$," to appear at the red cell surface and it reacts with an agglutinin " $T$ " present in all adult sera; it is apparently absent in newborn sera. The transformation process is generally known as the Hübener-Thomsen-Friedenreich phenomenon. The $T$ antibody is a specific cold agglutinin which is adsorbed by "changed" cells only. It exists apart from the other known specific antibodies.

Friedenreich (1930) isolated two coryneform bacteria, " $M$ " and " $J$," from old blood samples. Panagglutinability was induced either by direct inoculation of blood or with culture filtrates of these bacteria. Friedenreich also found that an enzyme with a similar action was produced by some strains of Vibrio, including Vibrio cholerae, and also by a strain of the Coccobacillus pierantonii. Other bacteria were added by later investigators, e.g., some strains of actinomycetes, especially among the acid-forming groups (von Magnus, 1936), a Gram-positive coccus (Terada, 1936), a Gramnegative coccobacillus (Kossovitch and Chabaud, 1938), a corynebacterium similar to the Orla-Jensen type, the Corynebacterium $H$ (Hektoenii) (Davidson and Toharsky, 1940, 1942), and Cl. welchii, Vibrio proteus, pneumococci of all types, and some species of streptococci and staphylococci (Chu, 1948).

Viruses of the mumps-influenza group are also capable of forming a T antigen (Burnet, McCrea, and Stone, 1946; Stone, 1947; Chu and Coombs, 1947) and, finally, the same effect results from treatment with snake venom (Briody, unpublished data), potassium periodate (Stewart, 1949; Moskowitz and Treffers, 1950), and also with trypsin under certain conditions (Rosenthal and Schwartz, 1951).

A similar phenomenon occurring in vivo has been less frequently observed. This is polyagglutinability of the red cells. Twelve well-documented cases have been described in the literature (Table I). In none of them was there convincing evidence that bacterial infection caused the polyagglutinability in vivo.

A further case, in which an organism was isolated from the urine of the patient which was able to render red blood cells panagglutinable in vitro, is described in this paper.

\section{Case History}

H.B., aged 25, was healthy until 1943. He then suffered from appendicitis and scarlatina. In 1946 he developed symptoms of pyelitis and was treated with sulphonamides. In the same year he was admitted to hospital at Djakarta because of amoebiasis and orchitis, probably following epidemic parotitis. By March, 1947, he had recovered. From April, 1947, onwards he has suffered from a relapsing infection of the urinary passages. This had been treated occasionally with sulphonamides, but without lasting effect. Pyelograms showed no abnormality, and cultures and guinea-pig inoculations were negative for tuberculosis.

A diagnosis of benign but persistent urinary infection, probably with prostatitis, was made. In June, 1951, the red blood cells were found to be polyagglutinable.

Serology and Urine Culture.-Till June 22, 1951, the patient's red blood cells (group $A_{1}$ ), containing a strong $A$ antigen, had been regularly used as test erythrocytes for blood group determinations without giving abnormal results. On this date, however, it was found that they were agglutinated by nearly all sera of the same blood group and also by $\mathrm{AB}$ sera. An investigation of the exáct frequency was not made at that time, but three days later the patient's corpuscles were titrated at four different temperatures against two normal A sera as well as his own serum (Table II). 
TABLE I

analysis of Cases of Polyagglutinability of Red Cells

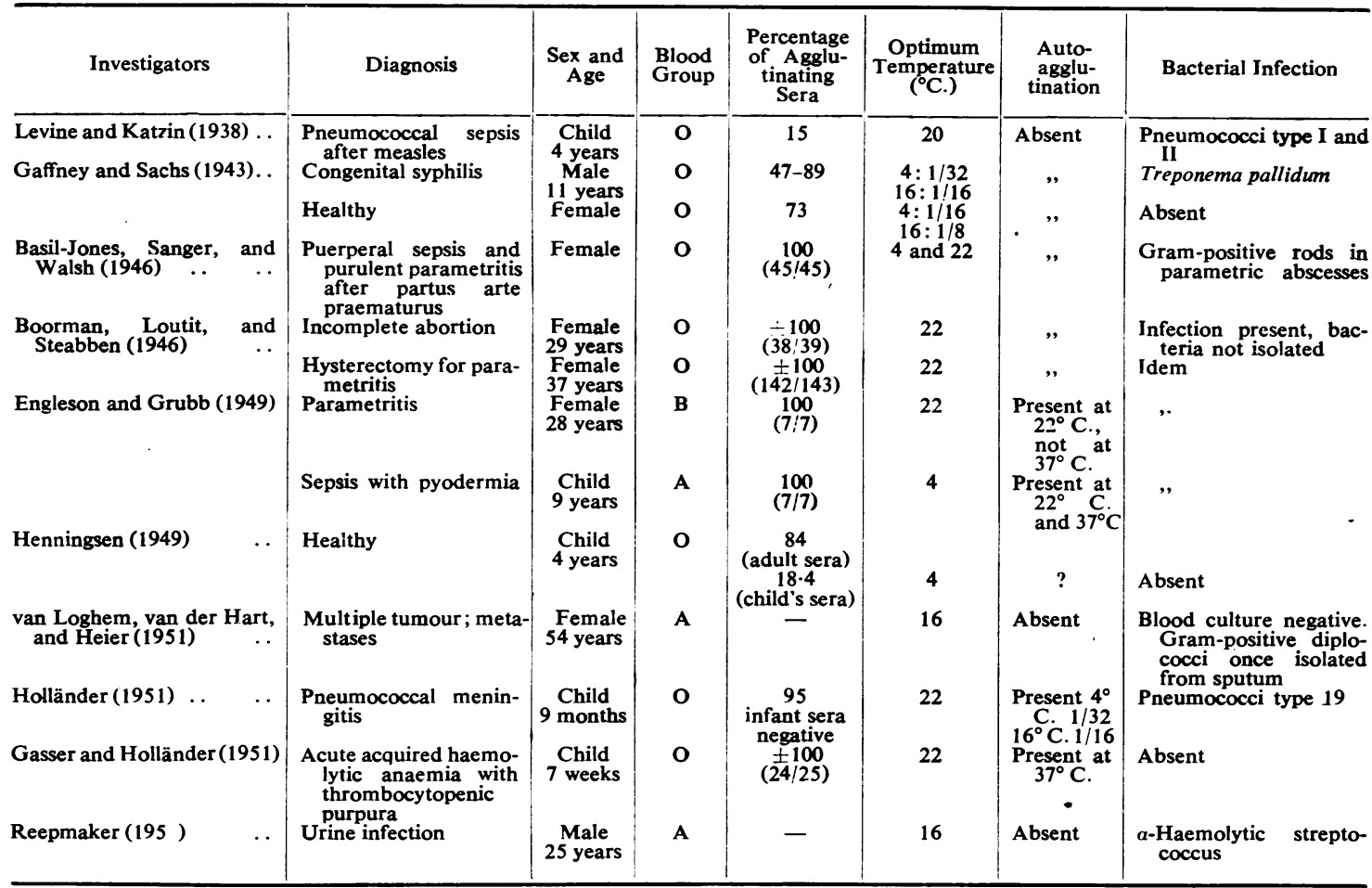

TABLE II

Agglutination Titres of Patient's Red Cells with Two Normal Grout a Sera and OWN SERUM at Four DifFerent TEMPERATURES

\begin{tabular}{cc|c|c|c|c}
\hline \multicolumn{1}{c|}{ Serum } & $4^{\circ} \mathrm{C}$. & $16^{\circ} \mathrm{C}$. & $22^{\circ} \mathrm{C}$. & $37^{\circ} \mathrm{C}$. \\
\hline Patient & $\ldots$ & $\overline{4}$ & $\overline{4}$ & $\overline{-}$ \\
A No. 11139 & $\ldots$ & $1: \overline{(+)}$ & $1: 2(+)$ & $1: 2 \sqrt{ \pm}$ & $\overline{-}$ \\
A No. 11141 & $\cdots$ & $1: 8(+)$ & $1: 8 \pm$ & $1: 8$ & $1: 1(+)$ \\
\hline
\end{tabular}

The strongest reactions and the highest titres were obtained at $4^{\circ} \mathrm{C}$. Auto-agglutination did not take place. By June 26, 1951, the polyagglutinability had totally disappeared.

In view of the history of chronic urinary infection the patient's urine was cultured to determine whether there was a relationship between the infection and the abnormal agglutinability of the red blood cells.

Two different micro-organisms were isolated and cultivated in broth. Filtrates made from these cultures were added to suspensions of thrice-washed group $\mathbf{O}$ erythrocytes which were then kept at room temperature for about an hour. The mixture was then centrifuged and the cells again washed three times. Two drops of a $4 \%$ suspension of treated cells were then added to two drops of $\mathrm{AB}$ serum on a slide and the reactions read after five minutes at room temperature. Only erythrocytes treated with a filtrate derived from a Gram- positive streptococcus were agglutinated by the $A B$ serum.

Further Investigations.-A filtrate of a four-day-old culture of the patient's streptococcus in serum broth proved to be the most useful for our experiments. The strain was dried in vacuo with phosphorus pentoxide in order to prevent variation through continuous re-inoculation. Dr. Skadhauge, from the Serum Institute at Copenhagen, kindly investigated the properties of this strain. It showed a-haemolysis on $5 \%$ blood agar and did not grow on $40 \%$ bile-blood agar. It did not split arginine with the formation of $\mathrm{NH}_{3}$, nor sodium hippurate. It fermented lactose, sucrose, and trehalose, but not mannitol, salicin, aesculin, inulin, raffinose, glycerol, glycogen, or arabinose. According to Dr. Skadhauge the streptococcus belonged to a species, also isolated from urine, which was discovered by Gardborg and Borgen (1951). Dr. Friedenreich, in a personal communication, reported that this Oslo strain also caused panagglutinability of red blood cells.

Preparation of Panagglutinable T Erythrocytes.-Four drops of packed red cells were added to a mixture of equal volumes of streptococcus filtrate and normal saline and the suspension left at room temperature for half an hour. After centrifuging the red cells were washed three times in saline so as to stop the activity of the bacterial enzyme. 
If they have been sufficiently transformed, they will be found to undergo agglutination within five to 10 minutes at room temperature in $\mathrm{AB}$ serum on a slide. If the cell filtrate mixture has been incubated for too long, the erythrocytes may undergo spontaneous agglutination in saline. It is noteworthy that Friedenreich (1930) also observed spontaneous agglutination as the result of the transformation process being carried on too far, but, contrary to our findings, this happened only when he used bacteria instead of filtrate.

Titration of $T$ Agglutinin.-To determine the T titre, doubling dilutions of the serum were made in test-tubes $(7 \times 60 \mathrm{~mm}$.). Two drops of a $4 \%$ suspension of transformed cells were added to two drops of the serum dilution. The reactions were read microscopically after one hour at $16^{\circ} \mathrm{C}$. and recorded as,,$+++(+)$, \pm , or -

Absorption of $T$ Agglutinin.-The $\mathrm{T}$ antibody was absorbed from one volume of a given serum with two volumes of transformed packed cells. After one hour at $16^{\circ} \mathrm{C}$. the cells were rapidly centrifuged and the supernatant titrated against $\mathrm{T}$ erythrocytes, as described above.

Elution of $T$ Agglutinin.-The $\mathrm{T}$ antibody was eluted from the $T$ cells used for the absorption test. For this purpose the cells were washed twice in cold saline and centrifuged. The supernatant fluid was pipetted off and replaced by two volumes of fresh saline. The mixture was shaken and kept for ten minutes at $45^{\circ} \mathrm{C}$. in a water bath. After rapid centrifugation the supernatant fluid was again titrated with $\mathrm{T}$ erythrocytes.

\section{Results}

As can be seen from Table III, the agglutination reactions at $16^{\circ} \mathrm{C}$. were stronger than at $22^{\circ} \mathrm{C}$. and $37^{\circ} \mathrm{C}$. The $\mathrm{T}$ agglutinin can thus be classified

TABLE III

Agglutination Titres of Streptococcus-treated Group O Rh-negative Rep Cells with Group aB Serum at FOUR DIFFERENT TEMPERATURES

\begin{tabular}{|c|c|c|c|c|c|c|}
\hline $\begin{array}{c}\text { Tempera- } \\
\text { ture }\end{array}$ & $1: 1$ & $1: 2$ & $1: 4$ & $1: 8$ & $1: 16$ & $1: 32$ \\
\hline $\begin{array}{r}4^{\circ} \mathrm{C} . \\
16^{\circ} \mathrm{C} . \\
22^{\circ} \mathrm{C} . \\
37^{\circ} \mathrm{C} .\end{array}$ & $\begin{array}{l}++ \\
++ \\
++ \\
+\end{array}$ & $\begin{array}{c}++ \\
++ \\
+ \\
+\end{array}$ & $\begin{array}{l}+ \\
+ \\
+\end{array}$ & $\begin{array}{c}+ \\
+ \\
(+) \\
-\end{array}$ & $\begin{array}{c}(+) \\
\pm \\
\pm \\
\pm\end{array}$ & $\begin{array}{l}- \\
\bar{z} \\
\overline{-}\end{array}$ \\
\hline
\end{tabular}

among the specific cold agglutinins. As a working temperature, $16^{\circ} \mathrm{C}$. is preferable to $4^{\circ} \mathrm{C}$., since non-specific cold antibodies, not identical with $\mathrm{T}$ agglutinins, are active at $4^{\circ} \mathrm{C}$. The amount of $\mathrm{T}$ agglutinin varies in different sera, titres varying from 1 in 4 to 1 in 64 (Table IV).

An experiment was carried out to see if red blood cells treated with the patient's streptococcus filtrate developed the same $T$ agglutinogen as cells treated with cholera filtrate. Erythrocytes from the same normal subject were treated with cholera filtrate in
TABLE IV

Agglutination Titres of Strfptococcus- and CholeraTREATED GROUP O RH-NEGATIVE RED CELLS WITH NORMAL SERA AT $16^{\circ} \mathrm{C}$.

\begin{tabular}{|c|c|c|c|c|c|c|c|c|c|c|}
\hline \multirow[b]{2}{*}{ Type of Cells } & \multicolumn{10}{|c|}{ Serum No. } \\
\hline & 5 & 6 & 7 & 9 & 17 & 15 & 17 & 19 & 26 & $\begin{array}{c}\text { Infant } \\
(4 \\
\text { months })\end{array}$ \\
\hline $\begin{array}{l}\text { Streptococcus- } \\
\text { filtrate- } \\
\text { treated cells }\end{array}$ & $\begin{array}{l}1 / 8 \\
(+)\end{array}$ & $\begin{array}{c}1 / 16 \\
\pm\end{array}$ & $\begin{array}{c}1 / 16 \\
\pm\end{array}$ & $\begin{array}{c}1 / 32 \\
\pm\end{array}$ & $\begin{array}{c}1 / 64 \\
\pm\end{array}$ & $\begin{array}{c}1 / 16 \\
\pm\end{array}$ & $\begin{array}{c}1 / 16 \\
\pm\end{array}$ & $\begin{array}{l}1 / 4 \\
(+)\end{array}$ & $\begin{array}{c}1 / 4 \\
\pm\end{array}$ & $\begin{array}{c}1 / 4 \\
\pm\end{array}$ \\
\hline $\begin{array}{l}\text { Cholera-fil- } \\
\text { trate-treated } \\
\text { cells }\end{array}$ & $\begin{array}{c}1 / 32 \\
\pm\end{array}$ & $\begin{array}{c}1 / 16 \\
(+)\end{array}$ & $\begin{array}{c}1 / 16 \\
\pm\end{array}$ & $\begin{array}{c}1 / 32 \\
(+)\end{array}$ & $\begin{array}{c}1 / 64 \\
\pm\end{array}$ & $\begin{array}{c}1 / 16 \\
\pm\end{array}$ & $\begin{array}{l}1 / 16 \\
(+)\end{array}$ & $\begin{array}{c}1 / 16 \\
\pm\end{array}$ & $\begin{array}{c}1 / 8 \\
\pm\end{array}$ & $\begin{array}{c}1 / 2 \\
\pm\end{array}$ \\
\hline
\end{tabular}

a manner similar to that described for the streptococcus filtrate. One volume of packed red cells was mixed with one and a half volumes of cholera filtrate and the mixture allowed to stand for one hour. Two parallel series of serum dilutions were made ; streptococcal-filtrate-treated cells were added to the first and cholera-filtrate-treated cells to the second (Table IV). The two types of cells behaved in almost the same manner.

It was next shown that streptococcal-filtratetreated cells specifically adsorbed the $T$ antibody from $A B$ serum, with the result that this serum failed to react not only with fresh streptococcalfiltrate-treated cells, but also with cholera-filtratetreated cells. Adsorption with cholera-filtratetreated cells gave the same result. It was also shown that an eluate of $\mathrm{T}$ antibody adsorbed by streptococcus-treated cells agglutinated both types of cells and the same was true of an eluate derived from cholera-filtrate-treated cells (Table V). It is concluded, therefore, that both $\mathrm{T}$ agglutinogens are serologically identical.

Finally, it was found that $\mathrm{Rh}$-positive $(\mathrm{D}+)$ erythrocytes treated with streptococcus filtrate were

TABLE $V$

Cross-ABSORPTION TEST

\begin{tabular}{c|c|c}
\hline & $\begin{array}{c}\text { Serum (No. 15) } \\
\text { Absorbed with } \\
\text { Streptococcus-treated } \\
\text { Red Cells }\end{array}$ & $\begin{array}{c}\text { Serum (No. 15) } \\
\text { Absorbed with } \\
\text { Cholera-treated } \\
\text { Red Cells }\end{array}$ \\
\hline $\begin{array}{l}\text { Streptococcus- } \\
\text { treated cells } \ldots \\
\begin{array}{c}\text { Cholera-treated } \\
\text { cells } . .\end{array}\end{array}$ & - & - \\
\hline
\end{tabular}

Cross-elution Test

\begin{tabular}{|c|c|c|c|c|}
\hline & $1: 1$ & $1: 2$ & $1: 4$ & $1: 8$ \\
\hline $\begin{array}{l}\text { Dilutions of Eluate from } \\
\text { Streptococcus-treated Cells: } \\
\text { Streptococcus-treated cells } \\
\text { Cholera-treated cells } \\
\text { Dilutions of Eluate from } \\
\text { Cholera-treated Cells : } \\
\text { Streptococcus-treated cells } \\
\text { Cholera-treated cells }\end{array}$ & $\stackrel{+}{+}$ & $(\stackrel{+}{+})$ & $\begin{array}{l} \pm \\
\pm\end{array}$ & $\overline{-}$ \\
\hline
\end{tabular}


agglutinated in saline by a serum containing incomplete $\mathrm{Rh}$ antibodies (anti-D) from which the $\mathrm{T}$ antibodies had been previously absorbed with T-positive Rh-negative cells (Table VI).

TABLE VI

Serum A.N. Containing InCOMPlete ANTI-D Titrated AGAINST STREPTOCOCC L- AND ChOlera-Treated Group O D Positive Cells in Saline at $37^{\circ} \mathrm{C}$.

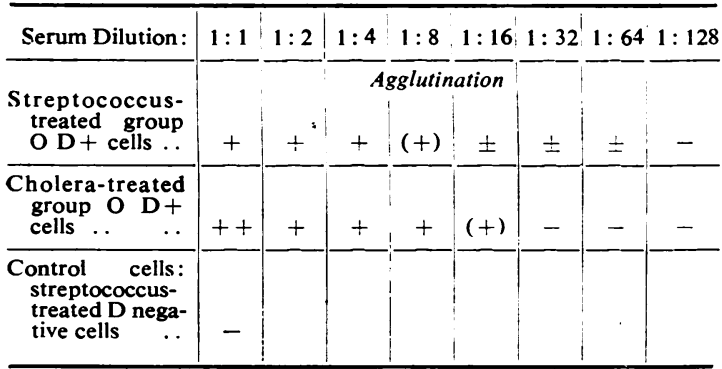

The analogous action of cholera filtrate was discovered by Pickles (1946). Chu and Coombs (1947) showed that Vibrio proteus, Cl. welchii, pneumococci, and some virus strains behaved in the same manner, and Hummel (1951) described this behaviour with a bacillus resembling Friedenreich's " $M$ " bacillus, which he had isolated from old stored blood.

\section{Discussion}

The observations now reported support the hypothesis that polyagglutinability of erythrocytes in vivo and panagglutinability in vitro may be induced by the same causal factor. In nearly all the published reports of polyagglutinability, except for the second case of Gaffney and Sachs (1943) and the case of Henningsen (1949), a bacterial infection was demonstrated as being the possible cause. The possibility that the abnormality of the red cells and the accompanying infection are related seems especially likely in the cases with pyogenic sepsis (Basil-Jones, Sanger, and Walsh, 1946; Engleson and Grubb, 1949) and in the two pneumococcal infections (Levine and Katzin, 1938; Holländer, 1951), because Chu (1948) demonstrated that these organisms might cause panagglutinability in vitro. However, no attempts seem to have been made to test for the ability of the isolated micro-organism to render red cells panagglutinable. Similarly, no clear relationship was demonstrated by van Loghem, van der Hart, and Heier (1951) and Gasser and Holländer (1951). In the case of van Loghem et al. (1951) it is possible that enzymes with activity similar to those derived from certain bacteria were released from neoplastic tissue (Rosenthal and
Schwartz, 1951). On the other hand, Gram-positive diplococci cultivated from the sputum could have been the cause of the abnormal agglutinability in this case.

Several authors showed that the erythrocytes of their patients behaved as did erythrocytes transformed in vitro (Gaffney and Sachs, 1943; Boorman, Loutit, and Steabben, 1946; van Loghem et al., 1951; Holländer, 1951). Henningsen (1949), however, found the agglutinin adsorbed by the cells of his blood No. 38 to be not quite identical with that adsorbed by actinomyces-treated cells.

It has been pointed out that the transient nature of polyagglutinability in vivo compared with the stability of the $T$ antigen and the regularity with which cells may be transformed in vitro is against the hypothesis that the two phenomena are identical. However, the apparent discrepancy between these two characteristics may be explained by the fact that body-temperature is unfavourable for the action of the enzyme on red cells. It is possible also that the presence of an enzyme inhibitor in human serum may weaken or prevent the reaction. It is worth noting in this connexion that Stack and Morgan (1949) found that the serum of rabbits immunized with enzymes from $\mathrm{Cl}$. welchii developed antienzyme properties. Finally, the transient character of polyagglutinability can be explained by the disappearance of the responsible enzyme with the elimination of the local infection. This was confirmed in our case.

It has often been stressed that in vivo the phenomenon is usually that of polyagglutinability, whilst in vitro the cells become panagglutinable. This is, however, not true of all the published cases (Table I), and certainly not true of those described by Engleson and Grubb (1949), Holländer (1951), and Gasser and Holländer (1951), where auto-agglutination took place.

It has also been stressed that it is not possible to transmit the polyagglutinability to fresh normal blood, as can be done with blood artificially transformed with bacteria. These failures, however, do not argue against the Hübener-Thomsen-Friedenreich phenomenon manifesting itself in vivo, because previous experiments have shown that sterile culture filtrates are able to produce this change. The author concludes that polyagglutinability of red cells in vivo is in most cases probably caused by infection with certain enzyme-producing bacteria. These bacteria need not necessarily be detectable by blood culture. The occurrence of the phenomenon in apparently healthy individuals remains unexplained. 


\section{Summary}

A case is described of a patient, aged 25 , with a chronic, relapsing urinary infection, whose erythrocytes showed the transient phenomenon of polyagglutinability in vivo. A short review of the literature is given, together with a list of the microorganisms known to cause the Hübener-ThomsenFriedenreich phenomenon in vitro.

An $\alpha$-haemolytic streptococcus was isolated from the urine of the patient. This organism was found to be capable of rendering red cells panagglutinable. It appeared to belong to the same species that Gardborg and Borgen (1951) isolated from urine and which had similar properties.

The $T$ agglutinogen that arises at the surface of normal red cells after treatment with a filtrate of this streptococcus was shown to be identical with the one resulting from treatment with cholera filtrate. It was demonstrated that incomplete antibodies (anti-D) could be detected in saline with $\mathrm{Rh}$-positive red cells previously treated with the bacterial filtrate.

The relationship between polyagglutinability of erythrocytes taking place in vivo and the HübenerThomsen-Friedenreich phenomenon is discussed. It is concluded that these phenomena are intimately related and most probably identical.

This paper has been prepared with the technical assistance of Miss J. Willems and Miss M. van der Hart, whom I wish to thank.

I am indebted to Dr. F. Dekking for the cultivation of the bacteria and to Dr. K. Skadhauge and Dr. V. Friedenreich for investigating the properties of the streptococcus.

All the clinical data were kindly provided by Dr. P. G. Hoorweg, of the Binnengasthuis, Amsterdam.
I wish to thank Dr. J. J. van Loghem, Jr., for his kind help and valuable criticism.

\section{REFERENCES}

Basil-Jones, B., Sanger, R. A., and Walsh, R. J. (1946). Nature, Lond., 157, 802.

Boorman, K. E., Loutit, J. F., and Steabben, D. B. (1946). Ibid., $158,446$.

Briody, B. A. Unpublished data.

Burnet, F. M., McCrea, J. F., and Stone, J. D. (1946). Brit. J. exp. Path., 27, 228.

Chu, C. M. (1948). Nature, Lond., 161, 606.

- and Coombs, R. R. A. (1947). Lancet, 1, 484.

Davidson, I., and Toharsky, B. (1940). J. infect. Dis., 67, 25.

- - (1942). J. Immunol., 43, 213

Engleson, G., and Grubb, R. (1949). Amer. J. clin. Path., 19, 782.

Friedenreich, V. Personal communication to the author.

- (1930). The Thomsen Hemagglutination Phenonenon. Copenhagen.

Gaffney, J. C., and Sachs, H. (1943). J. Path. Bact., 55, 489.

Gardborg. O., and Borgen, L. O. (1951). Acta path. microbiol. scand., 28, 116.

Gasser, C., and Holländer, L. (1951). Rev. Hémat., 6, 316

Henningsen, K. (1949). Acta path. microbiol. scand., 26, 339.

Holländer, L. (1951). Helv. paediat. Acta, 6, 149.

Hübener, G. (1925). Z. ImmunForsch., 45, 223.

Hummel, K. (1951). Ibid., 108, 233.

Kossovitch, N., and Chabaud, A. (1938). C.R. Soc. Biol., Paris, 128, 851 .

Levine, P., and Katzin, E. M. (1938). Proc. Soc. exp. Biol., N.Y., 39, 167.

Loghem, J. J. van, Hart, M. van der, and Heier, A. M. (1951). Bull. centr. Lab. Bloedtr. Ned. Rode Kruis., No. 2, 93.

Magnus, R. von (1936). Thesis, Undersögelser over en Gruppe Actinomyceter isolerede fra menneskets Svaelg (with English summary). Copenhagen.

Moskowitz, M., and Treffers, H. P. (1950). Scierice, 111, 717.

Pickles, M. M. (1946). Nature, Lond., 158, 880.

Rosenthal, M. C., and Schwartz, L. I. (1951). Proc. Soc. exp. Biol., N.Y., 76, 635.

Stack, M. V., and Morgan, W. T. J. (1949). Brit. J. exp. Path., 30, 470 .

Stewart, F. S. (1949). J. Path. Bact., 61, 456.

Stone, J. D. (1947). Aust. J. exp. Biol. med. Sci., 25, 137.

Terada, S. (1936). Thesis, $J$. med. Ass. Formosa, 35, 1285. Cited by Davidson, I., and Toharsky, B. (1940).

Thomsen, O. (1927a). Z. ImmunForsch., 52, 85.

- (1927b). C.R. Soc. Biol., Paris, 96, 556.

_- (1928). Z. ImmunForsch., 57, 301. 